\title{
Industrial heritage and post-industrial situation in the post-transformation era in Lower Silesia (Poland)
}

\author{
Jan Barski ${ }^{1, \otimes}-$ Maciej Zathey ${ }^{2}$ \\ ${ }^{1}$ HafenCity University, CityScience Lab, Überseeallee 16, 20457 Hamburg, Germany \\ ${ }^{2}$ Wrocław University of Technology, Faculty of Architecture, Department of Spatial Planning, ul. Prusa 53-55, 50-317 Wroclaw, \\ Poland \\ jan.barski@hcu-hamburg.de
}

\begin{abstract}
This descriptive paper outlines the post-industrial setting and industrial heritage in both a concrete case - south-western Poland - and some general respects, with the aim of contributing to the available knowledge about the contemporary post-industrial areas in Central Eastern Europe. To produce such an outline and to offer such a contribution, the paper offers an overview of the changes that happened in Poland since the transformation of 1989/90 with the special focus put on the industrial sector in the small- and mediumsized towns in the south-western border region of Poland. Moreover, the paper describes how the political and economic changes have impacted industry in Poland immediately after the transformation, as well as how the evolution of the political and economic situation has been shaping the industrial sector along the years until today. Further, to solidify the broad background of post-industrial regions, the paper touches upon topics that are more specific and interconnected: location of industry, employment rate changes, regional development policies, local development inequalities, and vocational schooling system. The most specific descriptions in the paper focus on the industrial heritage in the towns and cities in the region of Lower Silesia. Apart from reviewing the industrial history of Poland and of the selected western regions, this paper looks into the future by commenting on the transition between the so-called 2.0, 3.0, and 4.0 industry phases and discusses whether small- and medium-sized towns in the Polish border areas are able to become connected to the future industrial network.
\end{abstract}

\section{Keywords}

Industrial heritage, Industry,

History of industry

Transformation,

Post-socialist countries

Received:

27 March 2018

Received in revised form:

12 June 2018

Accepted:

15 June 2018

\section{Highlights for public administration, management and planning:}

- Political and economic factors that have impacted industry in Poland since the post-socialist transformation are described.

- It is claimed that the modern, postindustrial growth of metropolitan networks pushes some small- and medium-sized towns away from relevancy in recent industrial stages.

- The potential of small- and medium-size towns in SW Poland to be connected to industrial networks within transitions to new industrial stages is discussed.

\section{Introduction}

In the discussion on the transition between the respective 'forms' of industry - the so-called 1.0, 2.0, 3.0, and 4.0 - a fundamental and indispensable realisation that must be highlighted is that independence from purely geographical, physical factors is a relatively new phenomenon. The novelty of the last handful decades in the research on industry location factors is the observation of industries becoming decreasingly tied to the geographical circumstances of particular plots, cities, but also regions and countries. Industrial culture 'as we know it' has been created by the untilrecently-natural subordination of settlement systems to the location and functions (production rhythm) of industry. In the past, industrial facilities were dependent on natural resources, and this dictated their location; labour, in turn, migrated following jobs. Industrial culture has significantly 
influenced society: it has created social groups and social strata - labourers, industrialists, but also bourgeoisie - and heavily impacted, if not altogether created, the modern city lifestyle and the life of a city. The birth and growth of industry, along with industrial culture, has caused the concentration of population in cities, and evoked completely new functions, services, and phenomena, such as mobility, mass consumption, mass education, new professions, or standardisation and uniformisation of lifestyles. In a more contextualised view, socialism and communism, and the major and minor revolutions associated with them, have directly emerged as a result of the formation and evolution of industrial culture. Moreover, in both the socialist/communist and the capitalist 'versions', industrial culture has, until recently, not accounted for what we call today the paradigm of sustainable development. With these remarks in mind, this paper wishes to offer an overview of the Polish and Lower Silesian context of the emergence and development of industry and industrial culture as a case that contributes to the overall discussion on this topic. In particular, the paper offers an overview of the changes that happened in Poland since the transformation of $1989 / 90^{1}$ with the special focus put on the industrial sector in the smalland medium-sized towns ${ }^{2}$ in the south-western border region of Poland, and provides specific descriptions focused on the industrial heritage resulting from the processes above and their relevance for current transition between the so-called 2.0, 3.0, and 4.0 industry phases.

\section{Overview of the industrial and economic history of Poland between WWII and today}

\subsection{The period before, during, and shortly after WWII}

By mid-19th century, the Industrial Revolution has swept through Europe, making chimneys of steel and cotton mills a staple of the landscape of many regions of the continent. It has been fuelled - literally and metaphorically - by coal mining and put in motion by the railway. The United Kingdom was the cradle of the Industrial Revolution and that is where it blossomed the soonest and the strongest, however the countries of continental Europe were quick to follow; a front-runner among them was the Kingdom of Prussia (which later shape-shifted into the Empire of Germany).
Between 1795 and 1918, the Polish state did not exist and the territory it now occupies was being developed by three foreign powers: the empires of Russia, Austria-Hungary, and Germany, with the German state having a clear advantage in general development over the other two. As a result of this period and together with the pre-partition heavy inequalities, even though the era of partitions ended a hundred years ago, developmental differences that represent the former partitions are easily noticeable in Poland until today.

The region that this paper describes in the most detail, however, Lower Silesia, is not among the territories that belonged to the Polish crown when partitions took place; it was an integral part of the Kingdom of Prussia. Coal mining is documented to have existed in that region since the 16th century but it intensified in early 19th century and certainly took off after the introduction of the railway in the 1840s. The region had a couple of clusters (to use a contemporary term) in the textile, glass, timber, and agricultural produce-processing industries. Lower Silesia was a decently-developed province and its capital, Wrocław (then Breslau), was among the largest cities in Germany.

More significant investments in industry marked the periods preceding each of the two world wars. During WWII, however, investment has been virtually stopped and maintenance suffered heavily as well. Resources such as coal were being extracted at a high rate, while industrial facilities and infrastructure deteriorated. The above describes the part of the war before the arrival of the front; in the last year of the conflict, bombings and land operations caused much damage to the industrial tissue in the region.

The Potsdam conference decided the new borders in much of Europe and Lower Silesia became part of Poland. After 1945, in the eastern half of the newly-delineated Poland much of the industrial tissue was destroyed or damaged and in consequence the majority of industry there was built from scratch. In the western part, however, largely taken over after Germany, the war damages were significant as well but much of the industrial infrastructure was possible to be put back to operation relatively easily. Later, however, more maintenance effort was concentrated on the new industry in the central parts of the country. As a result, after the transformation, the new reality found the industry in the west of Poland in a higher state of degradation on the whole than in the central and eastern parts of the country.

Due to the severe destruction and damage all over the country and the urging need to begin rebuilding, any and all mines and factories whose op- 
eration could be restored quickly were being prioritised, and at nearly any cost. Those facilities that were the closest to being functional did not see investment apart from provisory repairs, which means that in the case of many industrial and mining sites the poor-but-operational condition carried over to the post-war era. Two more factors may also be mentioned at this point. One of them is the fact that with the two waves of mass migration (late-war escape migration and post-war forced resettlement) that drove the German population out of the territories conceded to Poland and Polish population into the newly-assigned land, the social and professional networks that allowed for a productive running of industry have been broken.

Despite the efforts of the new Polish administration to allocate skilled people between the facilities all over the country, the early post-war years were marked by a chronic shortage of manpower, which naturally influenced industry. The other factor worth mentioning is that during the very first months after the war, the Soviet army deconstructed and transported out of the formerly German territories an unknown-but-massive amount of infrastructure ${ }^{3}$, machines, and literally anything of technological and technical value that could be moved and rebuilt in the Soviet Union. The phenomena described here concern Lower Silesia slightly less than the other formerly German regions due to its initial relatively good industrial development, however the other side of this observation is that the social and economic problems that appeared after the fall of communism hit that province harder than the less-industrialised ones. In all, the above information serves to paint the first part of the background for the main discussion of this paper.

\subsection{The Polish People's Republic era}

Among the multitude of differences between the free-market economy countries and the centrally-planned economy ones is one that needs to be highlighted in the context of this paper, namely the phenomenon of deindustrialisation. The former type of countries began to experience that process in the 1960s: a good example of that is the beginning of the gradual decreasing of coal production in the Ruhr area in West Germany. The latter, however, can hardly be said to have experienced deindustrialisation (Muller et al. 2005:6). There definitely was decline in industrial efficiency and profitability but the importance of industry for the Eastern Bloc countries was fundamental from two perspectives: firstly, because these economies, devoid of the free flow of cap- ital and with the service sector limited to public services, relied on manufacturing to grow; and secondly, because of ideological implications, which put a premium on labour (industrial and agricultural). Two major, different policies introduced by European countries between 1945 and 1970 brought either industrial decentralisation or suburbanisation. The first, represented by socialist countries, aimed at redirecting growth from central to peripheral regions that were lagging behind (industrial decentralisation). The second one, observed in capitalist countries, promoted urban renewal and firm relocation to the outer zones of the cities and beyond (industrial suburbanisation), in order to cope with the rapid demographic and economic growth of the core areas (Weihong \& Huilong 2006:331-332).

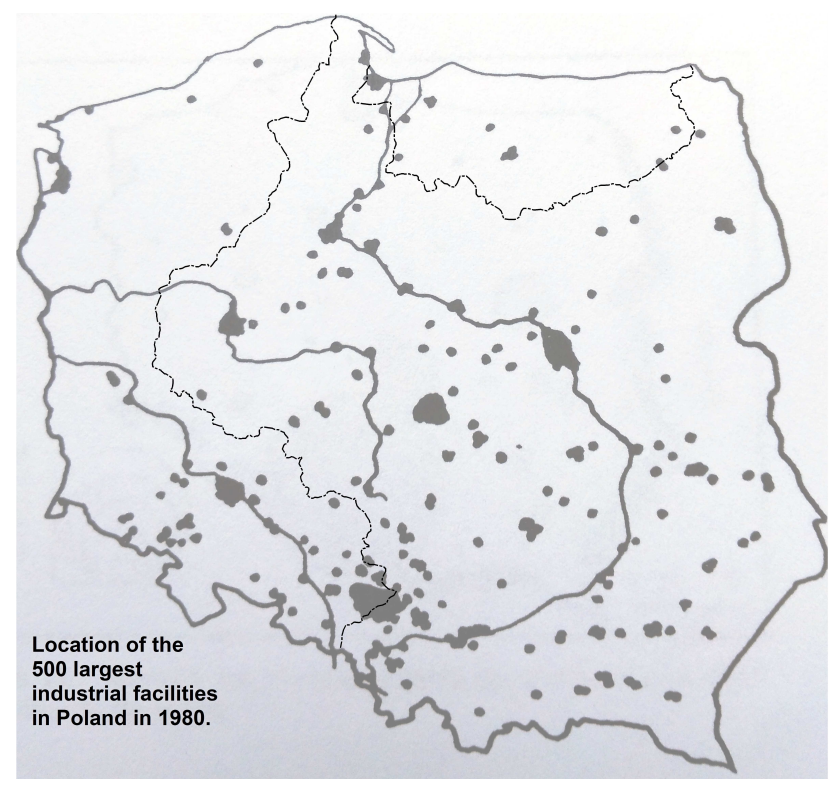

Fig. 1 The 500 largest industrial facilities in Poland in 1980. Pre-WWII borders marked (Kostrubiec 1987, modified by authors)

In over forty years of the existence of the socialist system in Central Eastern Europe, the growth of cities in them was detached from market mechanisms and subject to top-down decisions. The central decisions took into account local specificities to a meagre degree and instead executed the goals of the state. Urban growth was tightly controlled and processes such as suburbanisation were marginal; as a result, in the moment of transformation, cities in socialist countries were incomparably more compact than their western counterparts. A crucial fact, however, is that concentration was the doctrine in the urban scale; in the national (supraregional) scale, in turn, deconcentra- 
tion was the paradigm, as industrial and infrastructural projects were located following arbitrary decisions, frequently against the economic calculation, in some dispersion with the goal of strengthening the weakest regions.

Figure 1 presents the location of the 500 largest industrial facilities in Poland in 1980; the pre-war borders of Poland have been marked and serve to visualise the strong position of the central, "core Polish" territories, as well as the significance of the south-western territories taken over from Germany. To complement the information provided so far on the industry location decisions in the Polish People's Republic, two more illustrations shall be provided.



Fig. 2 Synthetic measure of the proportion of industrial capacity created in the years 1945-1989 to the total industrial capacity of each province (own image based on Karpiński et al. 2013)

Figure 2 presents a synthetic measure ${ }^{4}$ of the proportion of industrial capacity created in the years 1945-1989 to the total industrial capacity of each province. In it, we see that the values differ but stay in the $40-60 \%$ range. This means that the socialist era provided for around twofold increase in industrial capacity in those 45 years in the country. The medium-high value for Lower Silesia, $47.5 \%$, is the result of three main factors. Firstly, the values provided by the source research combine the industrial plants built from scratch with the ones that have been expanded; secondly, since the 1960s, two subregions of the province have seen concentrated investment, namely the LegnicaGłogów copper-mining district and the Bogatynia lignite-mining area with the accompanying major power plant; and thirdly, because $31 \%$ of all investment in Lower Silesia happened in Wrocław, which had suffered tremendous damage during the war. Therefore, the value of the synthetic measure for the whole of the remaining part of the province would be different and lower. Therefore, some of the dots marking the largest industrial facilities on the previous figure (1) stand for plants that had been built before the territory changed ownership.

\subsection{The transformation and the early 1990s}

The transformation period in Central Eastern European countries, although tumultuous, may be called relatively peaceful in terms of social unrest when the rapidity and overwhelming scale of changes are taken into account. The initial decisions taken in these countries had fundamental and overarching consequences on their development moving forward ${ }^{5}$. The Polish reformers were aware of the fact that the "shock therapy" will be especially troubling for the industrial workers and farmers, and that it will put many people in difficult situation or even leave them without the means to support themselves. The CEE countries differed in their approaches: for instance, the Czech Republic and Slovakia risked an economically protectionist early security measures for large state-owned industries, which cushioned the unemployment spike in the early 90s. The collapse of the heavy industry ${ }^{6}$ the backbone of the economy of Polish People's Republic - caused a crisis in production and exports, a drop in wages, the disappearance of workplace social care facilities, and undermined the union protection of workers. A quick re-establishment of employment in such industrial plants was extremely rare because foreign capital was not interested in taking over obsolete, unprofitable steel mills, mines, or fertiliser plants. Foreign investment in anything more advanced than simple assembly (i.e. in R\&D, knowledge, and high tech) only started appearing in post-socialist countries past 2000 (Bohle \& Greskovits 2007). Moreover, these countries' own capital capacities were held back by the interest on their foreign debt incurred in the 1970s or 80s.

While in the socialist era there was talk of labour shortage with the parallel phenomenon of hidden unemployment, in the early 1990s there was a surplus of labour and a rapidly growing 'open' unemployment rate (Zajdel 2010:337). Much of industry - and very frequently large industrial plants - turned out to be unprofitable for a myriad of reasons ${ }^{7}$; in the case of small- and medium-sized towns that frequently meant a crisis for the whole town. 
Many of the dramatic changes were, however, necessary and unavoidable. The socialist production sector was economically inefficient and did not even possess the capability to satisfy the domestic market. Similarly, it was not capable of competing the international competition after the market became open for both imports and exports. The sector was characterised by over-centralisation and low flexibility and innovativeness. The many social problems stemming possibly from overreliance on the self-healing powers of the free market were the direct result of the collapse of industry after the transformation (Karpiński et al. 2013). The introduction of the free-market rules, such as land rent, competition, or the free flow of people and services, made the backwards Polish industry (suffering from low product quality, high production costs, and sometimes also from the afore-mentioned poor location decisions) lose its importance quickly and go bankrupt or go through painful restructuration (Sikorski 2013). To bring up an example from Lower Silesia, the decision on discontinuing coal mining in the Wałbrzych ${ }^{8}$ (ger. Waldenburg) area was made in 1990 due to difficult geological conditions that made extraction unprofitable. Coal mining stopped in that city in 1996 (in the region in 2000) and caused the disappearance of thousands of related jobs. In 2002, the unemployment rate in this 100000 -inhabitant city reached $27.7 \%$. Around that time, a special economic zone was created (and later, for instance, managed to draw an investment from Toyota $^{9}$ ) but naturally was unable to accommodate everyone. Some miners and related professionals emigrated to Spain, some to Upper Silesia (where mines have been closing as well), some underwent requalification, but many ended up chronically unemployed. A similar fate was shared by many monocultural towns across Poland.

\subsection{The period between mid-late 1990s and today}

In the late 2000s, Polish industry began regaining some power and significance. This came as a result of a combination of factors: foreign investment, maturation of economy, adjustment to the global market, and many more. To illustrate the positive but late advancement of the Polish industry, the partly state-owned KGHM (the coppermining conglomerate), one of the richest companies in Poland and one of the very few Polish entities capable of investing abroad, has only recently begun processing its own resources instead of merely selling them on the global market. Between 1987 and 2007, the share of the industrial and construction sectors combined in total employment decreased from $36.3 \%$ to $29.0 \%$, but on the way it observed a dip (25.2\% in 2001), after which it bounced back a couple of percentage points. The figure for the year $2006(29.6 \%)$ has Poland above the EU-27 average (25.0\%), but, for instance, at the exact same share of this sector as in Germany (Zajdel 2010). Two main conclusions can be drawn from here: (i) that the sector of industry and construction still provides for a lot of jobs despite the crash resulting from the decomposition of obscure, heavy socialist-era industry; and (ii) that the move towards the western-type economy relying strongly on the so-called services and selfemployment is fuelled largely by the shift away from traditional forms of economy, mostly from labourintensive related professions. The relatively large proportion of industrial jobs is a topic for discussion from a few points of view, particularly in the strategic economic aspect (the idea of reindustrialisation of Europe; the question of sustainability of industrial economic growth), and the aspects of ecology and image (the good reputation of "green" industries vs. the bad classical reputation of industry in general). In the 25 post-transformation years of Polish history, however, the number of available industrial jobs at times seemed even too low for the economic needs of the country, keeping in mind the direst unemployment phases $(20.0 \%$ in 2002); since then, these values have gone through the moderate unemployment rate not long ago (11.6\% in April 2015) to the recent record-low (8.2\% in November 2016). Moreover, astonishing regional differences remain: Wrocław, the capital of Lower Silesia, had its unemployment rate at 2.8\% in February 2017; Wałbrzych at 19.9\%. Additionally, a worrying fact that must be pointed out as a warning is that the main advantage with which Poland has recently successfully competed on the global market is the low cost of labour. This is clearly not a sustainable means to continued economic growth and the Polish economy will face a significant challenge concerning this matter.

Another issue that needs attention are the territorial inequalities and imbalances, and one of the ways to measure them is the location of jobs. In Poland, between only 2004 and 2010, the number of jobs in predominantly urban regions ${ }^{10}$ rose by $20 \%$, while in the mixed type by $10 \%$, and in predominantly rural regions by $9 \%$; at the same time the concentration ratio increased, which means that jobs increasingly concentrate in and around large cities (Adamczyk 2014). Although the direction of change - growth - is not surprising, the dynamic of it may be. These figures illustrate the fast urbanisation and the power of the largest settlements in the country. 
The above information is complemented well by numbers describing the phenomenon of industrial suburbanisation. In the last 20 years, industry in large cities decreased noticeably, while their peripheries observed significant growth. This mechanism is based on a couple of mutually-reinforcing factors: the preference of foreign capital to greenfield investments (which naturally finds the cheaper and more readily available urban fringe locations more attractive), the frequent impossibility of adapting old-industry facilities to modern requirements, the territorial competition (in which rural communes located around cities are able to offer cheaper land and other preferable conditions to investors), and finally the crucial factor of access to transportation (peripheral urban locations usually mean closeness to a motorway). The scale of industrial suburbanisation is visualised on the illustration below on the example of Wrocław (Fig. $3)$.

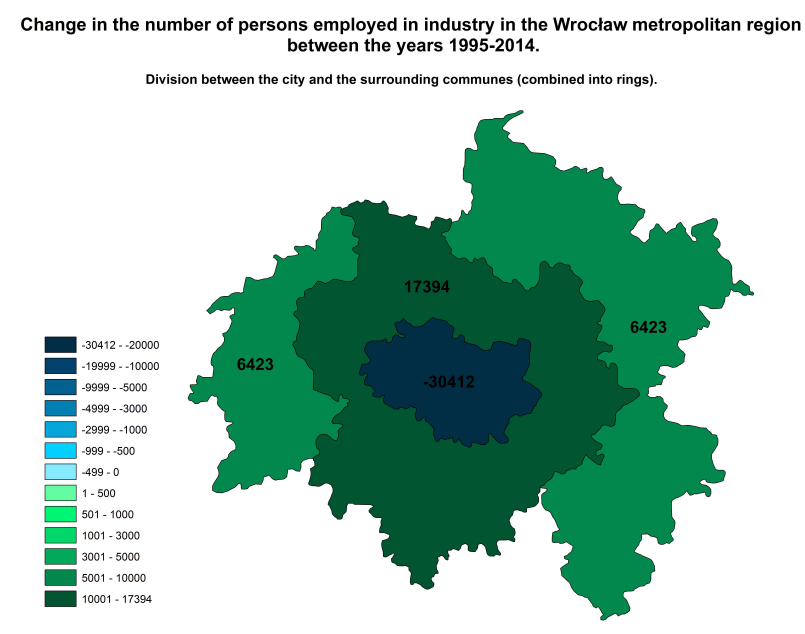

Fig. 3 Industrial suburbanisation in the Wrocław metropolitan region in the years 1995-2014: depicted as a change in a number of persons employed in industry in the Wroclaw metropolitan region between the years 1995-2014 (division between the city and the surrounding communes) (source: own analysis)

\section{Current situation}

To this, the notions of lifestyle, people's preferences, and their psychology may be added. The significant decrease in labour needed in farming, the decline of many small industrial towns, the allure of big-city lifestyle coupled with dropping attractiveness of living far away from the attractive cities, and the national and international brain drain all contribute to the negative migration ratio of interiors of regions in Poland. The numbers on emigration require a deeper insight because of the imperfection of the domicile registration system: many people who live outside of Poland still have their home address in the country; and similarly, many new city-dwellers keep their domiciles in their places of origin. This decreases the legibility of emigration data. From the psychological point of view, a quick look at the image of industry may be brought to attention. The industry itself, as a notion present in people's minds, is much different today than its stereotype suggests. It is surprisingly easy to overlook the fact that the bad name (although deserved to a large extent) of this particular human activity has its roots in the time at least a couple of decades ago, in the era of massive steel mills and coal power plants, or even further back in time, in the 19th century steam engine technology, red-brick buildings, and chimneys polluting vast areas of human settlement. Today, however, clean technologies are on the rise that have a tangible economic impact by frequently proving more profitable than "dirty" industries; and modern industries put much effort into their image by trying to prove their harmlessness to the natural environment and human habitats. In all, the traditional dogma of the incompatibility of the industrial function with the functions associated with high quality of life - residential or recreational needs to be at least partly reviewed. Leaving aside the often-suboptimal aesthetic side of industrial developments, many of them do not pose a threat to residential areas, which is exemplified in the many suburban areas in Poland as well as around the world.

Transportation represents a fundamentally important matter in all discussions concerning industry. Frequently, however, it is viewed from an overly technical perspective without the inclusion of the human aspect. To quickly discuss the scientific side of that topic, an outline of industry location factors may be presented. As early as in 1909, Max Weber, in an attempt to perfect an even older theory, presented a summarised mechanism of optimising the location of an industrial project. Weber named three factors: transportation cost, labour cost, and benefits of agglomeration (also called economies of agglomeration). He pointed to the transportation cost as the most important one due to its share in the cost of production reaching $20-40 \%$ and it being the product of the mass of resources and the distance on which they need to be moved. From there, Weber posited that the optimal location for industry is in the area of the lowest transportation cost; 
it may be altered to some extent if the positive impact of other factors is great enough to compensate for the increased cost of transport (Wieloński 2005:38). The above are, of course, hundred-yearsold observations but the fundamental importance of transportation for industry has remained unchanged. Troughout the 20th century, of course, the set of factors has been changing. The importance of connections between cities - understood as the network of business and professionals and not merely transportation connections - has become more prominent, while the traditional rooting in the region where an industrial plant is located has become less significant. The result of that is the dissolution (sometimes to zero) of the importance of factors like the 'influence zone' of a plant or the dependence on local topographic and environmental factors, which are replaced by aspects such as tax reliefs or financial services (Zipser 1997:50). These mechanisms come together to produce a paradoxical phenomenon, hinted at earlier in the paper: on the one hand, in the scale of a country and even a continent, the concentration of people in large cities is stimulated; on the other, the urban tissue of large agglomeration is becoming deconcentrated. Finally, it needs to be realised that commute has also become viewed more broadly than in used to. For everyday home-work commute that spans dozens of kilometres an example from Lower Silesia will suffice, where one of the largest industrial companies (belonging to the ones that appeared on the outskirts of Wrocław in the 2000s) organises shuttles for its employees that go far into the region; moreover, that is the standard in numerous agglomerations that are able to boast having efficient urban railway systems. Meanwhile, for high-end professionals who do not need to commute daily but, for instance, twice a week, far larger distances are feasible, as can be seen in densely urbanised regions like north-west continental Europe or the American north-east Megapolis.

Finally, this paper wishes to address once more the perspective that needs to be prioritised: the people of the industrial heritage regions. The city (and its general area) that has been mentioned earlier, Wałbrzych, is still struggling with the consequences of the crisis caused by the clumsy process of shutting down the coal mines. Firstly, the area has been developed (also in pre-WWII era) as a monoculture, which means it was purely reliant on coal production and industrial activities related to it. Then, after the transformation, the 'motor' of development has been taken away from the community but nothing cohesive and promising has been offered in return. Anger and frustration stemming from the (now dropping) unemployment are all emo- tions with deep roots in this city (Bendyk et al. 2015:232). As in many places suffering from similar fate, one of the ways of recuperating have been cultural and social initiatives, which attempt to revitalise historic buildings, local culture, recreation and tourism, etc.; that, however, is a solution just for a small part of the problem though and is far from enough. Part of the solution may be provided by the state or the provincial authorities, however overreliance on these is also pathologically unsustainable. The potential of rehabilitation of an area is thus complemented by the third group of solutions, namely bottom-up economic actions. These include initiatives that may be referred to as industrial clusters, networks, or cooperatives. In his seminal work, Porter emphasised the importance of local tradition and cultural background as the fertile ground on which industrial clusters may flourish. Such an environment allows manufacturers to offer products that are easily distinguishable on the market thanks to their quality and integrity - and thus strong brands and wide renown (Porter 1998). Porter's main example was that of northern Italy, where networking cooperation in many trades has centuries-old tradition and has recently found new life in the globalisation era $^{11}$. Global manufacturers mostly profit from uniformisation of tastes, preferences, cultural codes, and consumption patterns; local producers have a good chance in competing with corporation by offering regional flavours of products, authenticity, and sustainability, and also by fillings niches. Undoubtedly, however, the challenge is even greater in regions where the industrial heritage has gone through a metaphorical earthquake, as it did in postsocialist countries with the sudden turn to freemarket economy.

\section{Closing remarks and the outlook to the future}

The future of industry, and therefore of industrial culture, is being determined quickly; 'as we speak', to use a popular phrase. We are experiencing a post-industrial culture, in which production is highly automated, the labour social class is shrinking, and a new class is emerging: the socalled creative class. Today's industry location factors revolve much less around geography and resources, and much more around financial services cost and access to the creative-class workforce. The world has not yet fully embraced the digitalised industry 3.0, while the next generation is already being conceived. Moreover, the 4.0 generation will 
not be the last: a new generation of automatisation - namely more intelligent, more universal robotisation, and finally artificial intelligence - is very likely the marker of future industries. It is astonishing how little of that notion perpetrates to the public discussion because one could make a bold claim in saying that it is not migrations that will disturb the quiet life of societies but the next (or ongoing, depending on the point of view) industrial revolution; one that will vastly trim the numbers of required labour. Regions of industrial heritage that will not have re-composed themselves in one of the many possible ways will then find themselves facing only more challenges.

Thus, industrial heritage becomes the challenge at hand. Settlement structures, cities, regions, and communities shaped by industry now undergo changes. An interesting proposition to consider is that much of the industry-induced urbanisation would never come to existence today, i.e. with today's factors of creation and running of industrial activity. In the perspective of small- and medium-sized cities, and especially those of industrial heritage, a point for discussion could be made by claiming that the modern, postindustrial growth of metropolitan networks pushes them away from relevancy ${ }^{12}$. New technologies disrupt the centuries-old processes and dependencies, which causes industrial heritage to evolve from assets (e.g. industrial traditions, experienced workforce) to liabilities (such as high unemployment, social problems, or degraded areas). The challenge, then, is to find, and keep finding, for such towns, cities, and regions functions and activities that are socially, economically, and environmentally feasible. Including industrial culture in that effort is nothing short of crucial, as it represents both tangible, physical artefacts, as well as intangible, soft values that need to be incorporated in the solution to the problem. In that regard there are hardly any universal prescriptions but multiple individual solutions.

\section{Notes}

1 This text shall use the term 'post-transformation' as an adjective referring to the time after 1990.

2 The Central Statistical Office of Poland defines small cities as having below 20000 inhabitants, medium-sized ones between 20000 and 100 000, and large cities as being above 100000 inhabitants. This categorisation may be found in many publications of the Office; an example could be the following report: http://stat.gov.pl/cps/rde/xbcr/gus/oz_miasta w liczbach 2009 notatka infor.pdf (GUS 2009).

${ }^{3}$ If the phrasing 'amount of infrastructure' looks ungrammatical, the authors would like to beg the reader's pardon; it has been de- vised to describe a tumultuous time when port and railway infrastructure, electrical equipment, and sometimes even power lines were being chopped down, dismantled, and packed onto cargo trains headed east.

${ }^{4}$ The authors of the source research provide three indicators of increase in industrial capacity in this period: productive assets, value of production, and employment. The synthetic measure is the average of the three.

5 To simplify, against the dilemma 'free market vs protectionism', the Vysehrad countries (Poland, Czech Republic, Slovakia, and Hungary) represented an eclectic (or chaotic) approach confusingly shared by both the rightist, leftist, and centrist governments; the Baltic states and Slovenia opted for one of the clearer paths (liberal for the Baltics and protectionist for Slovenia) (Bohle Greskovits 2007).

6 To offer an example from Budapest - the capital of Hungary which dominates over the country - in 2001 the number of industrial jobs in the city was 21\% lower than in 1989 (Keseru 2004:4).

${ }^{7}$ The Authors would argue that afore-mentioned dispersion has been among these reasons, however this needs to remain a point for a different discussion.

8 Wałbrzych is, according to the official categorization, a large city, however the authors have taken the liberty of including it in this discussion due to its being narrowly above the threshold (120 000 inhabitants) and, most of all, of its being a compelling story.

9 Cities below 100000 inhabitants and small towns are not to be found among the top ten spots in the FDI ranking, which is dominated by the large cities; by 2012, Warsaw itself attracted $51.4 \%$ of all FDIs in Poland. Some of the small towns do appear in the second ten. These, however, are clearly small- and mediumsized towns and cities that have an industrial past. Wałbrzych finds itself among them (Głębocki Chrzanowska 2013:102-103). ${ }^{10}$ As defined by Eurostat.

${ }^{11}$ Conveniently, this volume includes a paper touching on exactly this topic (Negrelli, Pacetti).

12 One argument to support this claim in the region of focus of this paper would be the findings of demographic prognoses, which project many small- and medium-sized towns of Lower Silesia to decline significantly in size in the coming 20 years. The prognosis of the Institute of Territorial Development may be retrieved from https://irt.wroc.pl/aktualnosc309-prognoza_demograficzna_dla_gmin.

\section{References}

Adamczyk P (2014) Przestrzenna koncentracja zatrudnienia w polsce - wybrane aspekty teoretyczne i empiryczne. Roczniki naukowe ekonomii rolnictwa i rozwoju obszarów wiejskich 101(1): 7-14.

Bendyk et al. (2015) Polski węgiel. Wydawnictwo "Krytyki Politycznej", Warszawa.

Bohle D, Greskovits B (2007) Neoliberalism, embedded neoliberalism and neocorporatism. Towards transnational capitalism in Central-Eastern Europe. West European Politics 30(3): 443-466.

Głębocki K, Chrzanowska P (2013) Bezpośrednie inwestycje zagraniczne w polskich miastach. Economics and management 3 : 97-108.

Karpiński A, Paradysz S, Soroka P, Żółtkowski W (2013) Jak powstawały i jak upadały zakłady przemysłowe w Polsce. Muza, Warszawa.

Keseru I (2004) The transformation of commuting patterns in the functional urban region of Budapest. Transport Research Arena. Transport Solutions: from Research to Deployment - Innovate 
Mobility, Mobilise Innovation! Paris La Défense (France), 14-17 April 2014: 1-10.

Kostrubiec B (1987) L'image de l'industrie contemporaine polonaise. Hommes et Terres du Nord 2: 81-90.

Muller B, Finka M, Lintz G (2005 eds.) Rise and decline of industry in Central and Eastern Europe. A comparative study of cities and regions in eleven countries. Springer, Heidelberg.

Porter M (1998) Competitive advantage. Creating and sustaining superior performance: with a new introduction. Free Press, New York, London.

Sikorski D (2013) Rozwój i struktura usług na terenach przemysłowych $\mathrm{w}$ wybranych małych miastach województwa dolnośląskiego. Acta Universitatis Lodziensis Folia geographica socio-economica 15: 77-95.

Weihong C, Huilong W (2006) A literature review on firm migration of SMEs. In: Zhang H, Zhao RM, Chen L (eds.) Pro- ceedings of the Eighth West Lake International Conference on SMB. Hagzhou, P.R China. Marrickville, N.S.W., Australia, pp. 330-337.

Wieloński A (2005) Geografia przemysłu. Wydawnictwo Uniwersytetu Warszawskiego, Warszawa.

Zajdel M (2010) Trójsektorowa struktura zatrudnienia w polskiej gospodarce jako miernik rozwoju (wybrane aspekty). In: Woźniak M G (ed.) Spójność społeczno-ekonomiczna a modernizacja gospodarki. 16th ed.Wydawnictwo Uniwersytetu Rzeszowskiego, Rzeszów, pp. 336-347.

Zipser T (1997) Przemysł jako czynnik kształtujący strukturę przestrzenną systemu osadniczego. In: Olszewski L, Mozrzymas J (eds.) Struktury przemysłowe w gospodarce. Aspekty ekonomiczne, społeczno-kulturowe i polityczne. Wydawnictwo Uniwersytetu Wrocławskiego (Acta Universitatis Wratislaviensis, 1941), Wrocław, pp. 49-52. 